\title{
Broiler adaptation to post-hatching period
}

\author{
Adaptações pós-eclosão em frangos
}

\author{
Alex Maiorka ${ }^{1 *}$ Fabiano Dahlke \\ Maria Silvia Furquim de Azevedo Morgulis ${ }^{2}$
}

\section{- REVISÃO BIBLIOGRÁFICA -}

\section{ABSTRACT}

In the latest years more attention has been given to mechanisms for bird adaptation at post-hatching period by management of environmental conditions and formulations of diets offered during this period when digestive, immune, and thermo-regulating systems suffer slight changes. In posthatching period, digestive system is anatomically complete, but its functionality is still immature in relation to adult birds. The chick immunity depends on maternal antibodies transferred to egg just before laying. In addition, variations within thermal comfort zone might affect initial development of chick. For example, high temperatures may induce hyperthermia with dehydration, while low temperatures may lead to hypothermia responsible by pulmonary hypertension syndrome. In conclusion, productivity might be enhanced when good conditions are offered to chicks during the period from last embryo development to first days after hatching.

Key words: broiler, digestive system, immune system, thermoregulatory system.

\section{RESUMO}

Nos últimos anos, os processos adaptativos que ocorrem no período pós-eclosão têm recebido atenção especial através de controle de condições ambientais e manipulação de dietas específicas para este período, uma vez que os sistemas digestório, imunológico e termorregulador sofrem sensíveis alterações. No período de pós-eclosão, o sistema digestório está anatomicamente completo, mas sua capacidade funcional ainda está imatura se comparado à de aves adultas. Nesta fase, a imunidade é dependente dos anticorpos maternais que foram depositados no ovo antes mesmo da oviposição. Além disso, oscilações na zona de conforto térmica também podem influenciar o desenvolvimento inicial das aves. Por exemplo, temperaturas altas podem induzir a hipertermia com desidratação enquanto temperaturas baixas podem desencadeiar quadros hipotérmicos que levam à síndrome de hipertensão pulmonar. Concluindo, melhores índices produtivos podem ser alcançados quando boas condições são oferecidas aos animais no período que compreende o final do desenvolvimento embrionário e os primeiros dias após a eclosão.

Palavras-chave: frangos, sistema digestivo, sistema imune, sistema termoregulatório.

\section{INTRODUCTION}

The transition period from embryo to posthatching stage is critical to normal development of bird. Some practices, normally adopted at first days after hatching, may affect bird development, more specifically, digestive, immune, and thermo-regulatory systems. Although anatomically complete at final of the incubation period, these systems suffer considerable morpho-physiological changes after hatching, such as hyperplasia, hypoplasia, and cell differentiation.

${ }^{1}$ Departamento de Zootecnia, Universidade Federal do Paraná (UFPR), 80035 050, Curitiba, PR, Brasil.

${ }^{2}$ Departamento de Patologia, Universidade de São Paulo, 05509 900, São Paulo, SP, Brasil.

*Departamento de Zootecnia, Setor de Ciências Agrárias, UFPR. Rua dos Funcionários, 1540, Curitiba, PR, Brasil. E-mail: amaiorka@ufpr.br. Autor para correspondência. 
Considering the short life cycle of broilers in commercial production systems, when changes of post-hatching period are not properly managed it may be responsible by significant losses in broiler production chain. Some factors in interaction (as breeder age, post-hatching weight, diet nutrients, water quality, management, environmental temperature and humidity) may provide conditions for homeostasis and adequate bird development.

Many researches were carried out aiming to clear how these adaptive processes work by investigating cell proliferation, biochemical activities, and enzyme RNA expression. Here, we aim to review the main results found about post-hatching development and its influence on broiler growth.

\section{Digestive system}

For embryo development nutrients are supplied by egg, but after hatching chicks need to receive nutrients from relatively complex diets. So, their gastrointestinal tract requires a period for diet adaptation.

\section{Embryo nutrition}

In general, egg is constituted by $58.5 \%$ of albumen, $31 \%$ of yolk, $10.5 \%$ of eggshell and low proportion of carbohydrate. This chemical composition may ranges according to breeding age, breeding nutrition, and genetic line (VIEIRA \& MORAN, 1999). In spite of these variations in egg composition, it is suggested that broiler embryo receives around $40 \mathrm{~g}$ of water, $7 \mathrm{~g}$ of protein, and $5 \mathrm{~g}$ of lipids during developmental phase. In this period, yolk sac is the unique energy source, which also provides fat-soluble vitamins, essential fatty acids, neutral lipids, and phospholipids required for embryo tissue formation.

Embryo uses nutrients from yolk sac, as lipoprotein particles, which overtake the endodermic cell of blood vessels for reaching cells of embryonic tissues. Although some proteins might be used intact, most of them are used as amino acids because of the increase of proteinase activity with embryo development (TAUSSIG, 1965).

\section{Gastrointestinal tract development}

At hatching the chick digestive system is anatomically complete (OVERTON \& SHOUP, 1964), but its functional capacity is immature when compared to adult birds. The most evident changes are: increase of intestinal length, villus height and density due to the increase of numbers of enterocyte, goblet cells, and enteroendocrine cells (IMONDI \& BIRD, 1966; BARANYIOVA, 1972; BARANYIOVA \& HOLMAN,
1976). According to NOY \& SKLAN, (1998), MAIORKA et al. (2000) reported a faster small intestine development when compared to body weight during the last third of incubation period, reaching the maximum relative development between the $4^{\text {th }}$ and $8^{\text {th }}$ day after hatching. In contrast, other organs of digestive system, as gizzard and pancreas, did not show the same growth rate (UNI et al., 1999).

Feeding just after hatching seems to affect gastrointestinal tract development. MAIORKA et al. (2000) observed that the duodenum length and duodenum, jejunum and ileum weights increased with feeding 24 hours post-hatching. Water and, or feed restriction immediately after hatching also changed intestinal mucosa structure of broilers and these changes were more visible when there was both water and food fasting (MAIORKA et al., 2003).

Mucosa development is based on increase of villus height and density, which is the increase of epithelial cell number per area. This first event occurs due to a set of cytological events: cell renewal (proliferation and differentiation of cells located in crypt and along the villus) and cell loss (extrusion that occur at the villus tip). The balance between these two processes determines the intestinal mucosa turnover (proliferation - migration - extrusion) for villus height maintenance. This process spends around 72 hours in 4-day-old chicks and 96 hours in adult birds. Turnover unbalanced, due to a determined agent, lead to villus height changes. So, in case of increase of proliferation rate (mitosis) with absence, decrease or maintenance of extrusion rate, an increase of cell numbers might be found and, consequently, villus height increase.

Immediately after hatching, most energy and protein are used for intestinal growth. This preferential growth occurs regardless of feed presence (NOY \& SKLAN, 1999; MAIORKA et al., 2000). When these nutrients are not supplied by feed, newly hatched chicks use for intestinal growth the energy and protein from yolk sac. However, $20 \%$ of the residual protein of yolk sac consists of maternal immunoglobulins, and the residual lipids of yolk sac are basically triglycerides, phospholipids, and cholesterol (DIBNER et al., 1998). The use of these nutrients for nutritional purposes may deprive newly hatched bird to antibody protection. Moreover, phospholipids and cholesterol did have an efficient energy metabolic way so, they are better used as essential components of cell membranes. The authors also reported that even if all triglycerides in yolk sac were metabolized with $100 \%$ of efficiency, the maximum amount of energy produced would be around $9 \mathrm{kcal}$, which is less than the $11 \mathrm{kcal}$ required for chick maintenance during the first day of life. 
Therefore, we may suggest that residual components of yolk sac may not be used as amino acid and energy sources, because they are more important and useful to newly hatched chick as intact macromolecules (immunoglobulin, phospholipids, etc.) than as metabolized molecules.

By the way, a common incubation handling that affects chick development can be mentioned here. For enhancing incubation process efficiency, all chicks are removed together from the hatcher. But, eggs do not have the same hatching time, there is a difference from 24 to 36 hours among eggs of the same tray and within this period some chicks stay with no water and food. Studies of SKLAN et al. (2000) observed a linear decrease, 0.14 to $0.17 \mathrm{~g}$ per hour, in body weight of newly hatched chick when they were in hatcher. Hatchery management and transport to farm increase this fasting period, and many chicks suffer food and water fasting per 48 hours or more.

Changes occurred during the interval from hatching to first feeding may severely prejudice broiler performance since there is correlation between weight of first-week-old chick and slaughter weight.

On the other hand, physiological changes are related to increase in production and activity of digestive enzymes from pancreas and intestinal membrane (NITSAN et al., 1991), as well as from membrane transporters (SHEHATA et al., 1984).

Besides luminal digestion, the final stages of hydrolysis are performed by enzymes from brush border membrane, such as sacharase-isomaltase, peptidases, and phosphatases. In general, digestive enzymes are already in gastrointestinal tract at embryo phase, but seems to be necessary the presence of substrates to induce their activity. The sacharaseisomaltase expression, for example, is affected by changes in diet (TRABER et al., 1991).

During embryo development, disaccharide expression is limited due to low carbohydrate storage. But, this enzyme activity increases around two or fourfold during the two first days of age with further stabilization. This increase immediately after hatching is evident in birds, which are induced by ingestion of small amounts of high-carbohydrate feeds.

Newly hatched chicks have a reserve of pancreatic enzymes produced during embryo growth, but these reserves are not sufficient to substrate hydrolyze in lumen and to maintain the initial concentration, so, these enzyme levels decline just after hatching (NITSAN et al., 1991). The activities of digestive enzymes (units $\mathrm{kg}^{-1}$ of body weight), measured in pancreas and in intestinal lumen, increase with age, with maximum values found in pancreas at $8^{\text {th }}$ day after hatching for amylase and lipase, and at $11^{\text {th }}$ day for trypsin and chymotrypsin. In intestinal content, maximum activity was observed at $4^{\text {th }}$ day for lipase, at $11^{\text {th }}$ day for trypsin and chymotrypsin, and at $17^{\text {th }}$ day for amylase.

Birds fed immediately after hatching had higher trypsin, amylase and lipase activities in intestinal mucosa, which was correlated to higher intestinal weight and body weight (SKLAN \& NOY, 2000). Also, these authors reported that feed intake set off constant secretion of amylase and trypsin, although many studies had indicated that pancreatic enzymes are already in bird small intestine at embryo phase.

SELL et al. (1991) studied the specific activity of pancreatic amylase, lipase and trypsin in turkeys during embryonic and post-embryonic stages until the $8^{\text {th }}$ day of age. They found activities of amylase increased three-fold at $6^{\text {th }}$ day, lipase remained constant between $1^{\text {st }}$ and $8^{\text {th }}$ day, while trypsin had insignificant increase. However, total activity of pancreatic enzymes significantly increased after hatching. NIR et al. (1993) reported that low enzymatic activity in gastrointestinal tract during the first week of age might be limiting to digestion and, consequently, to broiler growth.

\section{Gastrointestinal microflora after hatching}

At hatching, chick gastrointestinal tract is still microorganism-free. But, after hatching, a significant number of microorganisms invade and colonize gastrointestinal from mouth to cecum. The balance of microbial ecosystem in proximal intestine is reached at second week of life, but this period should be longer in cecum.

In crop, there is predominance of Iactobacilli producing acid $\mathrm{pH}$ and in the proventriculus and gizzard the $\mathrm{pH}$ is extremely low, which allows colonization only by few bacteria. On the other hand, small intestine colonization of allows is broader due to its neutral $\mathrm{pH}$, being cecum considered the gastrointestinal segment with the largest number of microorganism.

The gastrointestinal microbiota is found in both ways, epithelium-associated or free in intestinal lumen. Its importance is related to mechanisms of pathogen competitive exclusion, especially because of lactic acid production and a not completely understood process of immune stimulation, which is benefic to chick intestinal health.

Gastrointestinal tract adaptation to exogenous feeding Poultry are able to digest carbohydrates, especially starch, as soon as hatching finishes. MARCHAIM \& KULKA (1967) affirmed that pancreatic 
$\alpha$-amylase is noticed approximately at $18^{\text {th }}$ day of incubation and its maximum of specific activity is reached 4 days after hatching. MORAN (1985) observed carbohydrate digestion and absorption rates are not predetermined in poultry, but they are highly dependent on presence of this substrate in diet. Enzymes responsible by the complete carbohydrate digestion are in surface of enterocyte brush border, and their proportion ranges according to substrate concentration.

Also, protein digestion system suffers significant adaptations during post-hatching period and, according to some studies, these changes depend on feeding level and diet composition. Following NOY \& SKLAN (1995), protein digestion in small intestine increased from $78 \%$ at $4^{\text {th }}$ day to $92 \%$ at $21^{\text {st }}$ day of age. But, ZELENKA (1995) demonstrated through two trials that crude protein digestibility was high at first 4-5 days of age, decreased at $5^{\text {th }}$ to $12^{\text {th }}$ day of age when started to increase until became constant.

Amino acid transport is also influenced by diet composition. High-protein diet increased amino acid absorption rate in intestine but, effect degree ranged according to amino acid type (AUSTIC, 1985).

Lipids are the main energy source of embryo during incubation. Approximately $80 \%$ of total lipid content of yolk sac is mobilized and used during the last 7 days of incubation. Interestingly, after hatching chicks do not have the digestion capacity completely developed, but it is improved with bird age. According to NOY \& SKLAN (1995), fatty acid digestion increased from $82 \%$ at day 4 to $89 \%$ at day 21 after hatching. Lipid metabolism depends on factors, such as the presence of bile salts, pancreatic lipase, colipase, fatty acid binding protein, and proper enterohepatic circulation. However, the physiological processes responsible by regulation of these factors are not completely developed in newly hatched birds, prejudicing negatively lipid digestion and absorption and leading to abnormal microbial growth in small intestine.

\section{Immune system}

Immune system development in broilers starts during embryonic period and continues after hatching. During the first seven days of life great part of immunity is constituted by maternal antibodies deposited in egg before laying.

Thymus and Fabricius bursa are the primary immune organs of birds, and the secondary organs are spleen, Harder gland, bone marrow, lymphoid tissue associated to conjunctiva, to bronchi, and to intestine. These lymphoid patches associated to different tissues play a very important role in bird immunity, particularly the lymphoid tissue associated to intestine, frequently colonized by several pathogens, which permit immune system to respond effectively (LILLEHOJ \& LILLEHOJ, 2000). The bursa of Fabricius, an essential organ for Blymphocyte maturation and antibody production, is strategically located in the final section of gastrointestinal tract, allowing the contact between immune cells and antigens present in diet (SHARMA, 1998).

Primary lymphoid organs, such as thymus and bursa, start to develop early in embryonic life. Thymus is already visible at $5^{\text {th }}$ embryonic day (ED); and at $6.5^{\text {th }}$ ED stem cells leave yolk sac and begin to colonize this area. The first CD3+ cell appear at $9^{\text {th }} \mathrm{ED}$, while $\alpha \beta$ and $\gamma \delta$ cells are detected at $12^{\text {th }}$ ED. However, $\alpha \beta$ and $\gamma \delta$ cells appear in intestine only after hatching, as well as the markers CD4+ and CD8+. Also, the first elements of bursa appear at $4^{\text {th }}$ day of embryonic development, and receive the stem cells derived from yolk sac at $7.5^{\text {th }} \mathrm{ED}$. In contrast, the humoral response will be mature only after the first week post-hatching (MAST \& GODDEERIS, 1999). Other secondary immune organs are partially developed only at hatching, and are capable to respond effectively as an immune challenger only at 10 days after hatching (MAST \& GODDEERIS, 1999). The development of lymphoid tissue associated to intestine is essential for chick survival, particularly during the first two weeks of life, when maternal antibodies are important for humoral response (YUN et al., 2000).

In poultry, immune response of intestine depends on several specialized organs, such as Peyer patches, cecum tonsils, and bursa; and also depends on different cell types, such as lymphoid cells, epithelial cells, antigen-presenting cells, and natural killer cells (LILLEHOJ \& TROUT, 1996). Other cells are also important: macrophages, mast cells, fibroblasts, and dendritic cells (YUN et al., 2000). As in mammals, the activity of these cells changes by action of cytokines released during immune response, allowing cell interactions and response coordination.

There are two maturation waves of lymphoid tissue associated to intestine in chick during the first and second week post-hatching, respectively (BARSHIRA et al., 2003). It was observed increase in mRNA transcription of IL2, cytokine produced by Tlymphocytes, and IFN $\gamma$ at $4^{\text {th }}$ day post-hatching, as well as an increase in population of cells expressing CD3, marker expressed by T-lymphocytes and by natural killer cells along all intestinal segments. Birds had basal levels of CD3 $\gamma \delta$ marker positive cells at hatching, but the population of these cells increased at $4^{\text {th }}$ day of age. 
Migrations of $\gamma \delta$ and $\alpha \beta$ T cells of thymus to peripheral lymphoid tissues by three different ways were studied by DUNON et al. (1997). The increase in number of $\mathrm{CD} 3+\gamma \delta$ cells in intestine was coincident with the second wave of colonization by thymusoriginated lymphocytes (BAR-SHIRA et al., 2003). The time between $\mathrm{CD} 3+\gamma \delta$ cell appearance in intestine and increase of mRNA transcription of IL2 and IFN $\gamma$ ( 6 days) suggested that cells need a period for tissue adaptation in order to respond actively against antigens present in intestine with production of cytokines (BAR-SHIRA et al., 2003). LOWENTHAL et al. (1994) observed that lymphocytes of one day-old chicks, although apparently mature, are functionally immature and gradually acquire immune activity.

In adult birds, the oral administration of protein antigens induced humoral responses verified not only at systemic level, but also at intestinal level, and they were not observed in immunized birds with less than 10 days of age (BAR-SHIRA et al., 2003). Lymphoid tissue associated to intestine has already Blymphocytes at hatching, and the number of these cells increased from $4^{\text {th }}$ day of age to two weeks of age. The capacity of intestine to develop humoral responses against antigens increased after this period. It is well known that young birds are able to use antigens administered by vent (JEURISSEN et al., 1994), but it was shown that before 8 days of age they were not able to produce antibodies when the antigen was administered by vent or orally (BAR-SHIRA et al., 2003). This period of low immune response against antigens present in diet may be important for the development of tolerance to antigens that birds should not respond because they are part of the broiler's normal diet.

The lack of a specific and well-developed humoral response during the first days of life leads chick to be very dependent of maternal antibodies. The antibodies IgM and IgA of amniotic fluid, which corresponds to colostrums in mammals, are ingested by embryo and has local role instead of the little transference (ROSE et al., 1974). The IgG antibodies are found in yolk sac and are absorbed from final incubation until yearly post-hatching period (KOWALCZYK et al., 1985; POWELL, 1987). Problems in antibody absorption may result in inadequate immunity. For compensate the slow absorption, the half-life of IgG in embryo is twice that observed in adult birds. IgA appears in serum at 10 days of age, and IgM at 4 days of age. IgM is the predominant immunoglobulin in bursa at hatching, and IgG present at this time is mobilized from yolk sac and represents the maternal antibodies deposited in yolk by hen.
The period between final stage of embryonic development and first days of life is coincident with a complex and sensitive stage of immune system maturation and thus, feed restriction during this period may significantly affect immune function.

Three mechanisms may be involved with immune system changes due to nutrition immediately after hatching (DIBNER et al, 1998). Firstly, feeding increases availability of substrates limiting for total development of lymphoid organs. Secondly, lack of feeding may affect the levels of endogenous hormones and other immune modulators, which are essential for the activity of these cells. Thirdly, the presence of antigens in gastrointestinal tract may be important for the complete differentiation and maturation of immune system, particularly of B-lymphocytes.

\section{Thermoregulatory system}

As well as mammals, birds are homeothermal, which means their body temperature ranges within narrowed limits regardless of large variations in individual physical activity or in environmental temperature. Therefore, a highly accurate control system for regulation of heat production and heat loss simultaneously is necessary. Bird thermoregulation system is based on four functional units: a) receptor, b) controller, c) effector, and d) passive system. The stimuli perception by receptors and its integration with nervous system induce the activation of mechanisms for control of body temperature. The participation of effector system induces responses for homeothermal maintenance. Therefore, we may suppose that temperature control in birds is based on the balance between two variables associated to responses against temperature elevation or reduction, assuming the existence of two different neuron populations in hypothalamus. Heat-responsive neurons are activated when body temperature increases for inducing heat-loss responses by bird; while, cold-responsive neurons are activated when body temperature reduces for inducing heat retention responses (FURLAN \& MACARI, 2002).

Implications about variation of environmental temperature during the first week of life

Thermal comfort zone should be defined as being the range of environmental temperature in which metabolic rate is minimal and homeothermal state is maintained with a minimum of energy cost. Therefore, in thermoneutral zone the proportion of metabolizable energy used for thermogenesis is minimal and net energy for production is maxima (FURLAN \& MACARI, 2002). 
The thermal comfort zone of chicks during the first week of life is between $33^{\circ}$ and $35^{\circ} \mathrm{C}$. Variations above or below this limit might clearly affect broiler development until slaughter age, once high temperatures induce hyperthermia with dehydration, while low temperatures lead to hypothermia, which can cause pulmonary hypertension syndrome (ascitis). Extreme temperatures (cold or heat) are stress factors responsible by increases in mortality and/or culling rates.

MALHEIROS et al. (2000) carried out a study for evaluating the consequences of temperature variation on development of broiler chicks submitted to three different environmental temperatures $\left(35^{\circ}, 25^{\circ}\right.$, and $20^{\circ} \mathrm{C}$ ) by measuring rectal temperature, skin temperature, radian thermal load, and broiler performance. Rectal temperature gradually increased with broiler age showing the maturation process of thermoregulation system after hatching. So, the temperature that was around 39 to $39.5^{\circ} \mathrm{C}$ at first day of life reached values around 40.5 to $41^{\circ} \mathrm{C}$ at $7^{\text {th }}$ day of age. This increase was associated to mechanisms of heat production and heat losses, as well as to the simultaneous capacity of bird to produce heat by oxidative metabolic processes for thermal homeostasis maintenance. It is important to comment that there is an effect of breeding temperature on thermal balance of chicks because birds reared under high temperatures had slightly higher rectal temperature than those reared in cold environments. However, how chicks are homeothermic animals after hatching, rectal temperature is maintained by spending metabolic activity even in cold weather, which means the combustion of nutrients from yolk sac and ingested feed. This fact suggests that the amount of nutrients available for growth is reduced when the weather is cold having, as consequence, productive performance prejudices.

Average skin temperature depends on rearing temperature, which is relevant for heat loss processes, since the average skin temperature is an important parameter for estimating heat loss by radiation. The capacity of heat loss in chicks by radiation mechanisms of skin surface is calculated in function of the temperature gradient between skin surface and environment, considering the surface area of chicks. This is calculated by HARDY (1949) equation: $\mathrm{RTL}=\varepsilon_{1} \varepsilon_{2}$ C.A. $\left(\mathrm{Tp}^{4}-\mathrm{Ta}^{4}\right)$; where: $\mathrm{RTL}=$ radiant thermal load in Watts (W); $\varepsilon_{1}=$ emissivity of bird surface (feathers $=0.94) ; \varepsilon_{2}=$ emissivity of environment (air = 1); $\mathrm{C}=$ constant of Stephan-Boltzman $\left(5.67 \mathrm{x} 10^{-8} \mathrm{~W} \mathrm{~m}^{-2} \cdot \mathrm{K}^{4}\right)$; $\mathrm{Tp}=$ mean temperature $\left({ }^{\circ} \mathrm{K}\right)$ of chick surface; $\mathrm{Ta}=$ environmental temperature $\left({ }^{\circ} \mathrm{K}\right)$, and $\mathrm{A}=$ chick surface area $\left(\mathrm{m}^{2}\right)$.
Heat loss by radiation is an important parameter, especially for cold environments, once it depends on a gradient between temperatures of chick surface and environment, and this gradient is at fourth potency. As a result, the amount of heat dissipated by chicks is significantly high. Heat loss by radiation mechanisms is lower in chicks reared at $35^{\circ} \mathrm{C}$ (thermal comfort zone) than that found in birds reared at $25^{\circ}$ or $20^{\circ} \mathrm{C}$.

Interaction between the digestive, immune, and thermoregulatory systems

According to results described above, we may hypothesize that the period between final stage of embryonic development and first days after hatching are essential for development of digestive system, immune competence, and adaptive processes of thermoregulatory system.

Chicks under temperatures below thermal comfort zone have lower feed and water intake than those reared under temperatures within thermal comfort zone. In cold environments, chicks show a typical behavioral response, such as crowding, which has the aim to reduce heat loss through environment and, thus, thermal homeostasis maintenance. So, the lower is environmental temperature, the longer is crowding, which implies in fewer visits to feeders and, consequently, in reduction of feed intake (MALHEIROS et al., 2000).

When chicks are submitted to temperatures slightly below to thermal comfort zone, no changes in weight gain can be found, demonstrating that chicks are able to gain weight and to maintain body temperature simultaneously. However, this mechanism has an expensive energy cost because the feed intake of these chicks is higher than that of birds within comfort zone.

In addition, temperatures above comfort zone promote reduction in feed intake aiming to decrease heat produced by nutrient metabolism. Also, physical activity decreases for reducing heat produced by muscle activity. MITCHEL \& CARLISLE (1992) mentioned that reduction of feed intake due to chronic exposure of broilers to high temperatures provoked decreases in small intestine weight and length, as well as in some villi characteristics.

Immune response is affected by thermal stress because corticosterone released may lead to lymphoid tissue involution (thymus, bursa, and spleen), as well as to suppression of humoral and cell-mediated immune responses (EDENS et al., 1983). At high concentrations, corticosteroids might atrophy thymus and bursa by apoptosis. Catecholamines also affect 
leukocyte activities and here are important immune organs innervated by adrenergic fibers, such as the spleen (ROGAUSCH et al., 1999). Chronic stress may lead to high serum levels of these hormones and may change the activity of immune cells. Similar to mammals, the exposure to neuroendocrine-threat substances may have a long-term effect on bird immunity (MORGULIS et al., 1999).

On the other hand, the effects of nutrient deficiency on immune system development during early broiler development must be also considered. Several nutrients are essential for the adequate development of bird immune system (KLASING, 1998) and when they are insufficient at early ages it can prejudice immune system work for the rest of bird life.

Under absence of exogenous feeding, chick uses only nutrients from yolk sac. Yolk sac reserves contain macromolecules, as maternal immunoglobulins, which are essential for bird protection during the first days of life. So, the use of these molecules for nutritional purposes during the first days of life deprives antibodyprotection of newly hatched chick and increases the risk of disease occurrences during whole bird life.

Lack of nutrients, which delay the complete development of gastrointestinal tract; and changes, caused by stress, in levels of hormones important for immune system, may cause improper work of organic defenses against challenges to which birds should be exposed during their productive life, allowing the occurrence of diseases.

\section{CONCLUSION}

Newly hatched chicks have an immature digestive system and face adaptive processes, particularly during the first week of life, in order to increase the efficiency of digestion and absorption processes. The development of immune system starts at embryo phase and continues after hatching, when it can be limited by diet nutrient availability. During the first week of broiler life the control of environmental temperature and its maintenance within the comfort zone is essential for development of mechanisms that allow proper physiological responses and work of defense mechanisms.

\section{REFERENCES}

AUSTIC, R.E. Development and adaptation of protein digestion. Journal of Nutrition, v.115, p.686-697, 1985.

BARANYIOVA, E. Influence of deutectomy, food intake and fasting on the digestive tract dimensions in chickens after hatching. Acta Veterinaria Brno. v.41, p.373-384, 1972.
BARANYIOVA, E.; HOLMAN, J. Morphological changes in the intestinal wall in fed and fasted chickens in the first week after hatching. Acta Veterinaria Brno. v.45, p.151-158, 1976.

BAR-SHIRA, E. et al. Establishment of immune competence in the avian GALT during the immediate post-hatch period. Developmental and Comparative Immunology, v.27, p.147-157, 2003.

DIBNER, J.J. et al. Early feeding and development of the immune system in neonatal poultry. Journal of Applied Poultry Research, v.7, p. 425-436, 1998.

DUNON, D. et al. Ontogeny of the immune system:gamma/ delta and alpha/beta $\mathrm{T}$ cells migrate from thymus to the periphery in alternating waves. Journal Experimental Medicine, v.186, p.977-988, 1997.

EDENS, F.W. et al. Grouping in japanese Quail. 2. Suppression and humoral immunity. Poultry Science, v.62, p.2479-2485, 1983.

FURLAN, R.L.; MACARI, M. Termorregulaçao. In:MACARI, M. et al. Fisiologia aviária aplicada a frangos de corte. Jaboticabal: Funep, 2002. p.209-230.

HARDY, J.D. Heat transfer. In: __ Physiology of heat regulation and the science of clothing. Phyladelphia: Saunders, 1949. p.78-108.

IMONDI, A.R.; BIRD, F.H. The turnover of intestinal epithelium in the chick. Poultry Science, v.45, p.142-146, 1966.

JEURISSEN, S.H.M. et al. Structure and function of lymphoid tissues of the chicken. Poultry Science Review, v.5, p.183207, 1994

KLASING, K.C. Nutritional modulation of resistance to infectious diseases. Poultry Science, v.77, p.1119-1125, 1998.

KOWALCZYK, K. et al. Quantification of maternal-fetal IgG transport in the chicken. Immunology, v.54, p.755-762, 1985.

LILLEHOJ, H.S.; LILLEHOJ, E.P. Avian coccidiosis. A review of acquired intestinal immunity and vaccination strategies. Avian Diseases, v.44, p.408-425, 2000.

LILLEHOJ, H.S., TROUT, J.M. Avian gut-associated lymphoid tissues and intestinal immune responses to Eimeria parasites. Clinical Microbiological Review, v.9, p.349-360, 1996.

LOWENTHAL, J.W. et al. Development of T cell immune responsiveness in the chicken. Immunology and Cell Biology, v.72, p.115-122, 1994.

MAIORKA, A. et al. Desenvolvimento do trato gastrointestinal de embriões oriundos de matrizes pesadas de 30 e 60 semanas de idade. Revista Brasileira de Ciência Avícola, v.2, p.141148, 2000.

MAIORKA, A. et al. Post-hatching water and/or feed deprivation affect the gastrointestinal tract and intestinal 
mucosa development of broiler chicks. Journal of Applied Poultry Research, v.12, p.483-492, 2003.

MALHEIROS, R.D. et al. Environmental temperature and cloacal and surface temperatures of broiler chicks in first week post-hatch. Journal of Applied Poultry Research, v.9, p.111-117, 2000.

MARCHAIM, U.; KULKA, R.G. The non-parallel increase of amylase, chymotripsinogen and procarboxypeptidase in the developing chick pancreas. Biochemical Biophysical Acta, v.146, p.553-559, 1967.

MAST, J.; GODDEERIS, B.M. Development of immunocompetence of broiler chickens. Veterinary Immunology and Immunopathology, v.70, p.245-256, 1999.

MITCHELL, M.A.; CARLISLE, A.J. The effect of chronic exposure elevated environmental temperature on intestinal morphology and nutrient absorption in the domestic fowl (Gallus domesticus). Comparative Biochemistry physiology A, v.101, p.137-142, 1992.

MORAN, E.T. Digestion and absorption of carbohydrats in fowl and events through perinatal development. Journal of Nutrition, v.115, p.665-674, 1985.

MORGULIS, M.S.F.A. et al. Benzodiazepine receptors and avian macrophage activity: diazepam decreases spreading and phagocytosis. Immunopharmacology and immunotoxicology, v.21, p.787802, 1999.

NIR, I, et al. Comparative growth and development of the digestive organs and some enzymes in the broiler chicks and egg type chicks after hatching. British Poultry Science, v.34, p.523-532, 1993.

NITSAN, Z. et al. Growth and development of the digestive organs and some enzymes in broiler chicks after hatching. British Poultry Science, v.32, p.515-523, 1991.

NOY, Y.; SKLAN, D. Digestion and absorption in the young chick. Poultry Science, v.74, p.366-373, 1995.

NOY, Y.; SKLAN, D. Metabolic responses to early nutrition. Journal of Applied Poultry Research, v.7, p.437-451, 1998.

NOY, Y.; SKLAN, D. Energy utilization in newly hatched chicks. Poultry Science, v.78, p.1750-1756, 1999.

OVERTON, J.; SHOUP, J. Fine structure of cell surface specializations in the maturing duodenal mucosa of the chick. Journal Cell Biology, v.21, p.75-82, 1964.

POWELL, P.C. Immune mechanisms in infections of poultry. Veterinary Immunology and Immunopathology, v.15, p.87-113, 1987.
ROGAUSCH, H. et al. Norepinefrine stimulates lymphoid cell mobilization from the perfused rat spleen via-b-adrenergic receptors. American Journal of Physiology, v.276, p.R724R730, 1999.

ROSE, M.E. et al. Immunoglobulin classes in the hen's egg: their segregation in yolk and white. European Journal Immunology, v.4, p. 521-523, 1974.

SELL, J.L. et al. Development patterns of selected characteritics of the gastrointestinal tract of young turkeys. Poultry Science, v.70, p.1200-1205, 1991.

SHARMA, J.M. Avian Immunology. In: PASTORET, P.P. et al. Handbook of vertebrate immunology. London: Academic, 1998. p.73-136.

SHEHATA, A.T. et al. Development od nutrient transporter system in chick jejunum. American Journal of Physiology, v.246, p.G101-G107, 1984.

SKLAN, D.; NOY, Y. Hydrolsis and absorption in the small intestines of posthatch chicks. Poultry Science, v.79, p.13061310, 2000.

SKLAN, D. et al. Decreasing weight loss in the hatchery by feeding chicks and poults in hatching trays. Journal of Applied Poultry Research, v.9, p.142-148, 2000.

TAUSSIG, M.P. Incorporation of aminiacids into chick proteins during embryonic growth. Canadian Journal Biochemistry, v.43, p.1099-1110, 1965

TRABER, P.G. et al. Isolation of intestinal epithelial cells for the study of differential gene expression along the crypt-villus axis. American Journal of Physiology, v.260, p.G895-G903, 1991.

UNI, Z. et al. Posthatch development of small intestinal function in the poult. Poultry Science, v.78, p.215-222, 1999.

VIEIRA, S.L., MORAN, E.T. Effects of egg and chick posthatch nutrition on broiler live performance and meat yields. World's Poultry Science Journal, v.55, p.125-142, 1999.

YUN C.H. et al. Intestinal immune responses to coccidiosis. Developmental and Comparative Immunology, v.24, p.303-324, 2000.

ZELENKA, J. Energy and protein utilization in chicks after hatching. In: EUROPEAN SYMPOSIUM ON POULTRY NUTRITION, 10., 1995, Turkey. Proceedings... Antalya: World's Poultry Science Association, 1995. p.29-43. 